DOI: https://doi.org/10.15407/techned2018.06 $: \underline{077}$

\title{
FEATURES OF USE OF ELECTRICAL VEHICLE CHARGER STATION IN URBAN ELECTRICAL NETWORKS
}

Journal

Publisher

ISSN

Issue

Pages
Tekhnichna elektrodynamika

Institute of Electrodynamics National Academy of Science of Ukraine 1607-7970 (print), 2218-1903 (online)

No 6, 2018 (November/December)

$77-80$

\section{Authors}

\section{V.B. Pavlov, V.O. Novskiy, V.A. Popov, S.O. Palachov}

Institute of Electrodynamics National Academy of Sciences of Ukraine,

pr. Peremohy, 56, Kyiv, 03057, Ukraine,

e-mail: novsky@ied.org.ua

\section{Abstract}

The application features of charging stations that are installed in multi-apartment buildings and public institutions of the megapolis and are intended for charging traction batteries of electric vehicles and hybrids are considered. The potential reserve of the active power of the electric grid for charging an electric vehicle at different times of the day is determined as well as the possibility of equalizing the daily schedule of the load of the distribution network by active use of chargers during minimal loads of household and office electric consumers. References 3 , figures 4 , table 1. 
Key words: electric vehicle, charging station, load graph, distribution electric network.

Received: 05.03.2018

Accepted: 14.05 .2018

Published: 23.10 .2018

\section{References}

1. State building regulations of Ukraine. Engineering equipment of buildings and structures. Designing electrical equipment for civilian objects. DBN V.2.5-23. Kyiv: Minrehionbud Ukrainy. 2010. 167 p. (Ukr)

2. Tulchin I.K., Nudler G.I. Electrical networks and electrical equipment of residential and public building. Moskva: Energoatomizdat, 1990. 480 p. (Rus)

3. Shydlovskyi A.K., Zharkin A.F., Pavlov V.B., Novskiy V.O. Influence of development of the charging infrastructure for electric vehicles and hybrid transport on modes of electric networks. Tekhnichna Elektrodynamika . 2018. No 3. Pp. 74-81. (Ukr) 